\title{
A KÖZVETLEN ÉRTÉKESÍTÉSI CSATORNÁK ÉS A HELYI TERMÉKEK KAPCSOLATÁNAK TERÜLETI ASPEKTUSAI
}

\author{
Nagyné Demeter Dóra - Szücs Antónia - Koncz Gábor
}

\begin{abstract}
Absztrakt: Tanulmányunkban arra keressük a választ, hogy a rövid ellátási láncok sikerét mennyiben befolyásolhatja a jelenlegi helyi termék kínálat, valamint az értékesítést biztosító helyi „hagyományos" piacok, termelői piacok, biopiacok száma és területi lehelyezkedése. Az ellátási láncot tehát a termelök és az értékesítési csatorna oldaláról közelítettük meg, két minta területen (Komárom-Esztergom, Heves megye). Mindkét megye területén, elsödleges és másodlagos adatbázisok segítségével mértük fel az említett tényezőket, külön megvizsgálva térbeli eloszlásukat, és az ebböl fakadó területi különbségeket. Vizsgálati eredményeinket összevetettük a rendelkezésre álló európai uniós források által kínált pályázati kiírás feltételrendszerével, lehatárolva a potenciális pályázók körét, a lehetséges REL-ek számát.
\end{abstract}

\begin{abstract}
In our study, we look for answers to the question of how can the current local product range influence the success of short supply chains? Especially local "traditional" markets, producer markets and bio markets that provide sales opportunity. So, the supply chain was thus approached from the side of the producers and the sales channels. We conducted research on two sample areas (Heves and Komárom-Esztergom Counties). In both counties, we measured these factors using primary and secondary databases. We paid special attention to their spatial distribution and the resulting territorial differences. Our results were compared to the tender conditions offered by available EU funds. Based on these, we defined the potential applicants and the number of possible short food supply chains.
\end{abstract}

Kulcsszavak: rövid ellátási láncok, agro-élelmiszer lánc, lokális élelmiszer lánc, fogyasztók, védjegyrendszer

Keywords: short food supply chains, agri-food chain, local food system, consumers, labelling scheme

\section{Bevezetés}

A hazai élelmiszerpiac az elmúlt két évtizedben jelentős koncentrálódási folyamaton esett át az értékesítési csatornák tekintetében. A kisebb méretü élelmiszer alapanyagot termelő és feldolgozó termelők a szövetkezés hiánya miatt, a megváltozott és kiélesedett piaci helyzethez nem tudtak alkalmazkodni. Ennek következményeként a stabilitásuk, jövedelmezöségük és fejlödési lehetőségük leszükült. Számukra jelenthet egy új lehetőséget az európai közösség által preferált rövid ellátási lánc, melyben megtalálhatják a saját piaci szegmensüket.

Az Európai Unió mind a $118 \mathrm{db}$ nemzeti és regionális vidékfejlesztési programjának vizsgálata alapján közel háromszázezer gazdálkodó számára teremtődik lehetőség hogy védjegyek, termelői csoportok és szervezetek tagjaivá váljanak, valamint a helyi piacok és a rövid ellátási láncok fejlődhessenek. Az Európai Parlament Mezőgazdasági és Vidékfejlesztési Bizottsága által 2016-ban készített tanulmány szerint az összes vidékfejlesztési program kiadásainak 10\%-át a 3. prioritásra fordítják. Ennek az öszegnek a 75\%-át áldozzák a 3A prioritásra, mely az élelmiszer láncok integrálásán keresztuil kívánja a versenyképességet fejleszteni. Kilenc tagállam a 3. prioritásra szánt forrásainak $90 \%$-át áldozza a fentebb említett $3 \mathrm{~A}$ prioritásra, míg csak öt olyan tagállam van akik kevesebb mint 50\%-át. (A 3 . prioritás az élelmiszer-ellátási lánc megszervezésének előmozdítását célozza meg. 
Két nagyobb területre oszlik. A $3 \mathrm{~A}$ prioritás az elsődleges termelők versenyképességének javítását célozza meg elősegítve az agrár-élelmiszerláncok létrehozását, az agrártermékek hozzáadott érték növelését, a helyi piacok, rövid értékesítési láncok valamint termelői csoportok, szervezetek kialakítását.)

A vidékfejlesztési források $7 \%$-át fordítják a rövid ellátási láncok fejlesztését célzó 3A prioritásra, mely közvetlenül hivatott növelni a termelők versenyképességét, akik ellátási láncok létrehozásán, védjegyek kibocsátásán keresztül, valamint az alapanyagok hozzáadott értékének növelésével, helyi piacok és ellátási láncok, termelői szerveződések és termék brand-ek promótálásával.

A programok közül a gazdálkodási feltételek javítását célzó fizikai beruházásokra, valamint az együttmüködések kialakítására dolgozták ki a tagállamok a legtöbb programot. Arányosan került be a szaktanácsadás és a tudástranszfer, melyek együttesen a tudásbázis bővítését eredményezhetik, javítva ezzel az együttműködések, a termelői szerveződések és a védjegyrendszerek müködtetését és életre hívását.

\section{1. ábra: Fejlesztési programok száma az egyes intézkedés csoportokon belül, a vidékfejlesztési program 3. prioritásán belül, 2016}

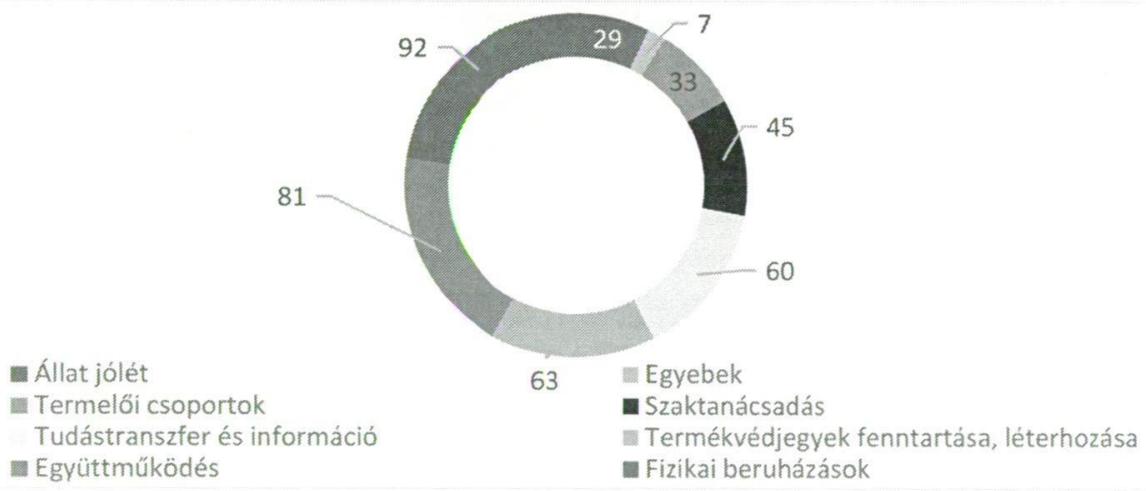

Forrás: European Network for Rural Development. EURural Review No 22 'Smart and competitive food and drink supply chains', 2016, alapján saját szerk.

Amíg a programok számában az együttműködések támogatása igen magas, a ráfordítások tekintetében már alapcsonyabb értékkel találkozunk (1. ábra). Ugyanezt az alacsony ráfordítást a védjegyek estében is tapasztalhatjuk. Bár a védjegyek alapvetően segítik a lokális, de még inkább a globális piacokon való térnyerést, a hozzájuk füzött remények nem teljesültek be. Már egy évtizeddel ezelötti kutatás is taglalta, hogy a termelői védjegyek a fogyasztók megítélése alapján jelentős hátrányban vannak a független tanúsítási rendszerrel, az eredetvédelem alatt álló és földrajzi árujelzővel rendelkező termékekkel szemben (Szabó, 2006). Emellett az uniós tagországokban végzett felmérések alapján a fogyasztók számára nem egyszerủ felismerni a helyi termékeket, és alig van információjuk arról, hogy hol tudják beszerezni őket. Esetenként a helyi és regionális márkák és védjegyek elburjánzása összezavarja a fogyasztókat. 
A fizikai beruházások támogatása nem csak az intézkedések számában, hanem a források lekötésében is kimagasló helyet foglal el. A hármas prioritás teljes költségvetésének közel 60\%-át teszi ki (2. ábra).

\section{2. ábra: Az egyes intézkedésekre tervezett ráfordítások megoszlása, 2016}

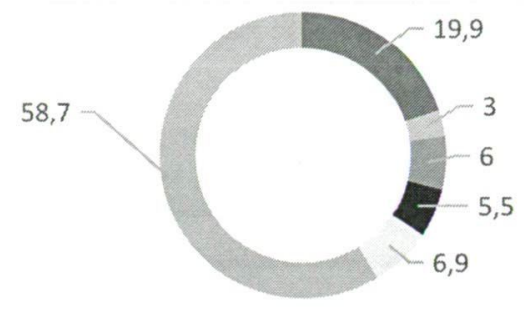

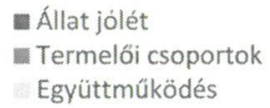

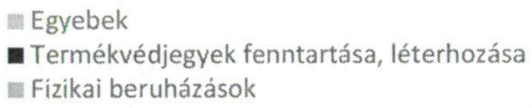

Egyebek

wizikai beruházások

Forrás: European Network for Rural Development. EURural Review No 22 'Smart and competitive food and drink supply chains', 2016, alapján saját szerk.

A rövid élelmiszerláncok csoportosítására többféle szempontot találhatunk a szakirodalomban: az értékesítés fizikai távolsága, az értékesítés területi kötődése, a marketing csatornák, a résztvevők száma és a részvétel formája, illetve az értékesítés fizikai megvalósítási formája (Kujáni, 2014).

Az Európai Unió tagállamaiban jelenleg is müködő értékesítési módokat az értékesítési mód alapján három nagyobb csopotra bonthatjuk (1. táblázat.

\section{1. táblázat: A rövid ellátási láncok egyik csoportosítása}

\begin{tabular}{|c|c|c|}
\hline Közvetl & Közö & Globális érték \\
\hline $\begin{array}{ll}\text { - } & \text { Termelői piac } \\
\text { - } & \text { Út menti } \\
& \text { értékesítés } \\
\text { - } & \text { Gazdaudvar } \\
\text { - } & \text { Szedd magad } \\
\text { - } & \text { Webáruház } \\
\text { - } & \text { „Heti szatyor” } \\
\text { - } & \text { (dobozrendszer) }\end{array}$ & $\begin{array}{ll}\text { - } & \text { Közösség által támogatott } \\
\text { mezőgazdaság } \\
\text { - } & \text { Értékesítés helyi } \\
& \text { vendéglátóknak } \\
\text { - } & \text { Értékesítés } \\
& \text { szupermarketeknek } \\
\text { - } & \text { Fesztiválok } \\
\text { - } & \text { Kamratúrák } \\
\text { - } & \text { Értékesítés kivándorlóknak } \\
\text { - } & \end{array}$ & $\begin{array}{ll}\text { - } & \text { Védett eredet } \\
\text { - } & \text { Specialitást } \\
& \text { tanúsító védjegy } \\
\text { - } & \text { Minőségbiztosítási } \\
\text { - } & \text { rendszerek } \\
\text { - } & \text { Tanúsítványok } \\
\text { - } & \text { Védjegyek } \\
\text { - } & \text { Helyi termék } \\
& \text { védjegyek }\end{array}$ \\
\hline
\end{tabular}

Forrás: Renting et al., 2003

Más megközelítések szerint a REL-ek alapvetően két nagyobb típusra bonthatóak (EIP-AGRI, 2015):

k) Hagyományos REL-ek, melyek a rurális térségek egyéni gazdaságaira épülnek, melyek az értékesítés terén elsősorban az „on-farm” értékesítési formákat preferálják: farm boltokat (Gazdaudvar), út menti értékesítés, 
„szedd magad” akciókat vagy termelöi piacokon való közvetlen értékesítést. Leggyakrabban családi gazdaságok üzemeltetik, és zömében hagyományos vagy kézmüves termelési és feldolgozási módokat alkalmaznak. (A hagyományos on-farm rendszer leggyakrabban az Egyesült Államokban fordul elö, a 2004-es kibövülés óta az EU-ban és mediterrán országokban is megjelent. Ez a rendszer a hagyományos off-farm rendszer értékesítési csatornáit a farmerek piacaiként értelmezi. A közösség által támogatott mezögazdasági rendszerek inkább Észak-Nyugat Európában jellemzőek, különösen Belgiumban és az Egyesült Királyságban.)

1) Neo-hagyományos REL-ek, melyek komplexebb irányítási mechanizmuson alapulnak, a termelök fogyasztók és az intézmények együttmüködési hálózata tart fenn, de gyakran törekednek a hagyományos gazdálkodási módok fenntartására új modellek alkalmazásával és társadalmi innovációkon keresztül. Ezek a rendszerek tartalmaznak például: szállítási rendszereket, városi gazda boltokat, közösségi tulajdonú városi vagy városi peremterületeken müködő gazdaságokat. Úgy léteznek, mint a helyi élelmiszer mozgalmak, ezért gyakran városi lakosok vezetik és támogatják öket.

m) Mind a rövid ellátási láncok, mind a helyi élelmiszerláncok esetében a szakirodalom általában az értékesítés alapján három föbb csoportot különböztet meg (EU Rural Review, 2012):

29. Közvetlen értékesítés önállóan (közbenső szereplö nélkül)

30. Közvetlen értékesítés közösen

31. Szövetkezés

Az 1305/2013-as EMVA támogatások felhasználásáról szóló rendelet szerint a rövid ellátási lánc „olyan ellátási lánc, amely meghatározott számú üzletkötőt foglal magába, elkötelezett az együttmüködések, a helyi gazdaságfejlesztés mellett, valamint földrajzi és társadalmi értelemben is közeli kapcsolatot teremt a termelök a feldolgozók és a fogyasztók között". Ezt a definíciót pontosította a 807/2014-es EU vidékfejlesztési támogatások nyújtásáról szóló rendelet, mely szerint „azok az ellátási láncok alapítása és fejlesztése támogatható, melyekben a termelők és a fogyasztók között egy közvetítő áll.” Franciaországban a Francia Mezőgazdasági Minisztérium a REL-ket olyam marketing módként értelmezi, melyben a termékeket a termelők a fogyasztók számára vagy közvetlenül, vagy legfeljebb egy értékesítési ponton keresztül értékesítik (EPSR, 2016). Tanulmányunkban ezt a definíciót követve igyekeztünk felmérni a két megye potenciális termelöi és termék bázisát.

A helyi élelmiszer láncok definíciója már bonyolultabb, ezért azok pontos definiálását tagállami hatáskörbe helyezte a korábban említett rendelet. Gyakorlatban a „helyi” meghatározást gyakran a termelő és az értékesítési pont közötti távolságként fejezik ki, melyek értelmezhetőek földrajzi területre, megyére vagy nemzeti parkra egyaránt. Az Európai Bizottság Közös Kutatóközpont tudományos és szakpolitikai tanulmányok alapján a REL-t és helyi ellátási lánc olyan élelmiszer lánc, melyben az előállítás, a feldolgozás és az értékesítés meghatározott földrajzi területen belül zajlik (a forrástól függően megközelítőleg 20-100 km -es 
sugarú kört lefedő földrajzi terület). A „helyi” élelmiszer fogalma pedig szubjektív és a helyi terület sajátosságaitól függ: népsürüség, elérhetőség, városi vagy vidéki jelleg. Ugyanakkor a helyi kifejezés utalhat a termelö és fogyasztó közötti kölcsönös bizalmon és együttmüködésen alapuló kapcsolat közelségére is (Kneafsey et al., 2013).

\subsection{A REL haszna a termelök és fogyasztók számára}

A rövid ellátási láncok gazdasági és társadalmi hasznosságáról több tanulmány és kutatás készült, az Európai Parlament által közreadott 2016-ban kiadott tanulmány ezen kutatások főbb megállapításait az alábbiak szerint összegzi (Dwyeret et al., 2016).

A növekvő mennyiségü helyi élelmiszer a helyi gazdaságot is fellendíti. Kifejezetten a perifériális leszakadó térségek számára nyújt kitörési lehetőséget. Hiszen a helyi élelmiszer láncok megerösítik az üzleti együttmüködést az élelmiszer láncok között, és munkahelyeket teremtenek, ezáltal a mezőgazdaságban és az élelmiszer előállításban. Az erős élelmiszer szektor előremozdíthatja a turizmus fejlödését, az élelmiszer termékek által képviselt helyi jellegzetességek erősítésével.

Emellett a helyi élelmiszerláncok a szociális kohéziót, közösségfejlesztést erősíthetik a kedvezőtlen helyzetü régiókban, ahol alacsony jövedelemtermelö képességgel bíró gazdaságok dominálnak, és a lehetőségek hiánya miatt a régióból történő elvándorlás jelentős. Az előbbieken túl hozzájárul a városi térségek társadalmi kohéziójához is azáltal; hogy újra összekapcsolja a lakosságot az élelmiszer előállító térségekkel, valamint azáltal, hogy friss minőségủ élelmiszert biztosít elérhető áron.

A közvetlen értékesítés előnyeit felismerve az európai gazdálkodók átlagosan 15\%-a a megtermelt áruk több mint felét önmaga értékesíti közvetlenül a fogyasztóknak. Ezek zömét a kis méretü gazdaságok (1-8 EUME) teszik ki, a 100 EUME méret feletti gazdaságoknak csupán 3\%-a értékesít közvetlenül a fogyasztóknak. A megoszlás nem csak a gazdaságok mérete, hanem területi elhelyzkedése alapján is megfigyelhető: amíg Görögországban (25\%), Szlovákiában (19\%) és Magyarországon (18\%) magasabb a közvetlen értékesítés aránya, addig egyes tagállamokban 5\%-ot sem éri el (Málta, Ausztria, Spanyolország). A francia gazdák esetében $21 \%$-os arányt mutat ez az értékesítési mód, azonban az így értékesített áruk fele zöldség és méz, azaz termékpályákra koncentrálódik. A RELek társadalmi támogatottsága Európában igen magas, hiszen az EUROBAROMETER 2016-os felmérése alapján tíz városlakóból kilenc véli úgy, hogy számára haszonnal jár, ha közvetlenül a termelötől tud vásárolni, míg ötböl négy városlakó egyetért azzal, hogy a termelők „erősítése” méltányos és nagyon fontos.

\subsection{A REL kialakításának akadályai}

A hazai termelők számára több ponton is nehézséget jelent az ellátási láncokba történő belépés. Noha több európai minta is a szövetkezés ezen típusának hasznosságát mutatja, hazánkban még nincs komolyabb rendszere ezen szövetkezési 
típusnak. Több kutatás rámutatott az országosan megjelenő problémákra. A föbb okok között említhető az árualap csekély volta, vagyis az egyedi, jó minőségü helyi termékek kis mennyisége, a szállítás, értékesítés, művelési mód és fajtaállomány megválasztása (a helyi tudás és fajták eltünése a nagyüzemi technológiák térhódításának köszönhetően), nem tudnak, vagy nem akarnak a szállítással, értékesítéssel foglalkozni, a kisléptékủ előállításból származó termékek egy része nem felel meg az elöírásoknak, ezért a hagyományos kereskedelmi csatornákon nem értékesíthető (Bocskay et al., 2013).

A termelési korlátok mellett egy másik igen komoly gátja is van a rövid ellátási láncok kialakításának: a szövetkezésekkel kapcsolatos komoly ellenérzések. A témában végzett empirikus kutatások rámutattak, hogy a gazdák nem szívesen vállalják a szövetkezésekkel kapcsolatos többletmunkát, nem látják pontosan, hogy „,ki járna jól” egy ilyen típusú együttmüködésben ebből az ellenérzésükből fakad, hogy összességében nem tartják profitábilisnak, ha részt vesznek a termelöi együttmüködésben (Kiss-Takácsné, 2017).

\section{Anyag és módszer}

Tanulmányunkban a szakirodalmi források áttekintése mellett szekunder és primer adatbázisokra támaszkodva próbáltunk elemzéseket végezni a két választott mintaterületen Komárom-Esztergom, valamint Heves megyében. Az adatok gyüjtésénél az ÁMÖ TEIR adatbázison keresztül elérhető gazdálkodásra vonatkozó adatokra támaszkodtunk. A vizsgálat során a csak önellátásra termelö gazdaságokat kizártuk, részvételük a REL-ekben nem releváns. A vizsgált térségekben felellhető helyi termékek körét az Ister-Granum régió által elkészített, tematizált termelöi címlista, a mátrai projektrégióban pedig az általunk 2013-ban készített helyi termelöi adatbázis alapján gyüjtöttük le. A helyi termékek osztályozásánál a Mátra térségére gyüjtött termelöi adatbázisra vonatkoztatva is az Ister-Granum régió által használt csoportosítást alkalmaztuk, az összevethetőség okán. A kutatás során feldolgozott adatbázis Komárom-Esztergom megyében összesen 41, míg Heves megyében 60 településre terjedt ki.

A termékek védjegyekkel kapcsolatos adatait a Szellemi Tulajdon Nemzeti Hivatalának elérhető adatbázisából, a termelői és helyi piacok a Nemzeti Agrárgazdasági Kamara, a biopiacok pedig a naturportal.hu oldalról származnak.

$\mathrm{Az}$ elemzések során a termékek és az elérhető piacok területi szintü összehasonlításánál az adatokat térképszerkesztő program segítségével dolgoztuk fel. A megyék településeinek vizsgált statisztikai adatait tartalmazó adatbázist ArcMap 10.1szoftverrel kapcsoltuk a települések közigazgatási területét tartalmazó vektoros térképi adatbázishoz. A szoftver segítségével a mennyiségi értékek alapján pontszórásos (Dot density) típusú tematikus térképeket készítettünk. Végezetül az egyszerü területi szintü elemzések adatait összevetettük a REL-ek létrehozását, müködtetését célzó pályázati kiírás szakmai tartalmával.

Lényeges kiemelni, hogy jelen tanulmány egy nagyobb léptékü, 2017-2020 között megvalósuló tematikus kutatási program első, helyzetfeltáró munkájának 
eredménye. A kutatás következő lépéseiben az itt leírt jelenségek pontosabb feltárására törekszik majd.

\section{Eredmények és értékelésük}

A vizsgálat során a termék előállítók és az értékesítés helyszíneit vizsgáltuk. Az árusítóhelyek esetében a szakirodalom alapján, Benedek és szerzötársai (2014) kutatásai alapján elkülönített típusokkal dolgoztunk:

32. Hagyományos (esetünkben: Helyi) piac: Az őstermelői igazolvány meglétén túl, nincs elöre meghatározva a termelés módja vagy annak helyszíne. Többnyire önkormányzati fenntartásúak, a kereskedök, illetve viszonteladók a meghatározóak.

33. Termelői piac: Az őstermelök 40 kilométeren vagy megyehatáron belülröl érkezhetnek. Ezeket a piacokat civil szervezetek vagy magánszemélyek szervezik.

34. Biopiac: Valamely hazai ökológiai gazdálkodást ellenőrző/tanúsító szervezet általi minősítés.

Az árusítóhelyek típusainak számszerủ és térbeli megoszlása mellett elsősorban a termék előállítóktól való távolságokat igyekeztünk felmérni, hiszen a jelenlegi szabályozás alapján $40 \mathrm{~km}$-es távolságot „tehet meg" a termék az előállítótól a fogyasztóig. A REL-ek szempontjából komoly potenciált jelentő biopiacok esetében Komárom-Esztergom megyében mindössze három (Dömös, Esztergom, TokodAltáró) piacot találtunk (4. abra), Heves megyében jelenleg nem múködik biopiac. Figyelembe véve, hogy utóbbi megyében 2013-ban 32 darab biogazdálkodót tartottak számon (3. ábra). Mivel a biogazdálkodásra elöirányzott központi források 2016-ban megduplázódtak, időszerü lehet az értékesítési oldal megerősítése a megyében.

A termelői piacok és helyi piacok száma közötti eltérés is számottevő, hiszen amíg Heves megyében 12 darab helyi piac és egyetlen kifejezetten termelöi piac létezik, addig Komárom-Esztergom megyében 23 darab piac közül 6 darab kifejezetten termelői piac, ahol a vizsgálatba bevont termék elóállítók jelentős piaci előnyre tehetnének szert. Figyelembe véve, a két vizsgált megye lakosságszáma (Heves: 299219 ezer fö; Komárom-Esztergom: 297914 ezer fö) és területe nem tér el egymástól számottevően, az értékesítési helyek számának helyen csak a területi versenyképességet befolyásoló különbségekből eredhet. Ez a további kutatások tárgya lehet. Mindkét megye esetében pozitívumként említhetö, hogy a rendeletben meghatározott $40 \mathrm{~km}$-es körben az értékesítési helyek a termékek számára elérhetőek, földrajzi értelemben vett korlát nem áll fenn. Továbbá az értékesítést segíti, hogy szintén mindkét térség számára könnyen elérhető Budapest. 
3. ábra: Heves megye termelői és helyi piacai, 2017

Jelmagyarázat

- kozitvonal

Heves megye

- Termelia Hely:

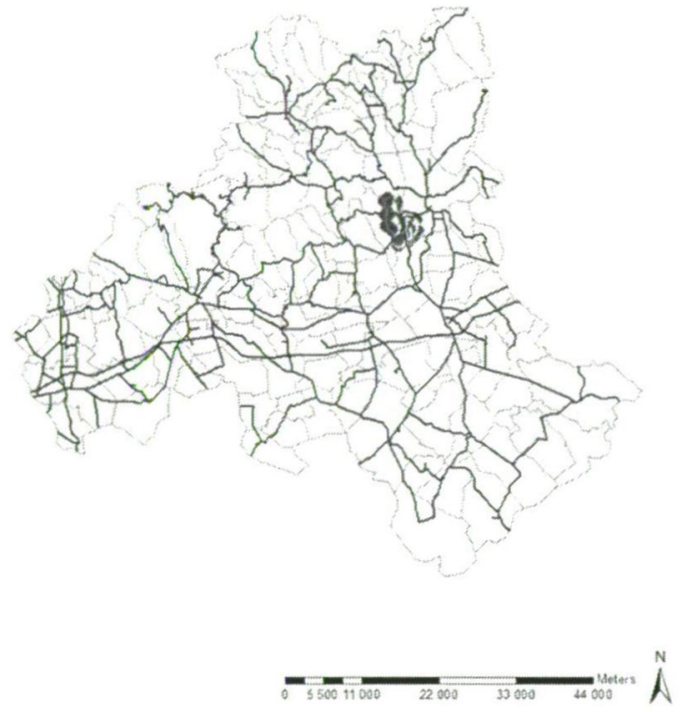

Forrás: NAK, valamint naturportal.hu adatai alapján saját szerkesztés

\section{4. ábra: Komárom-Esztergom megyében múködö piacok, 2017}

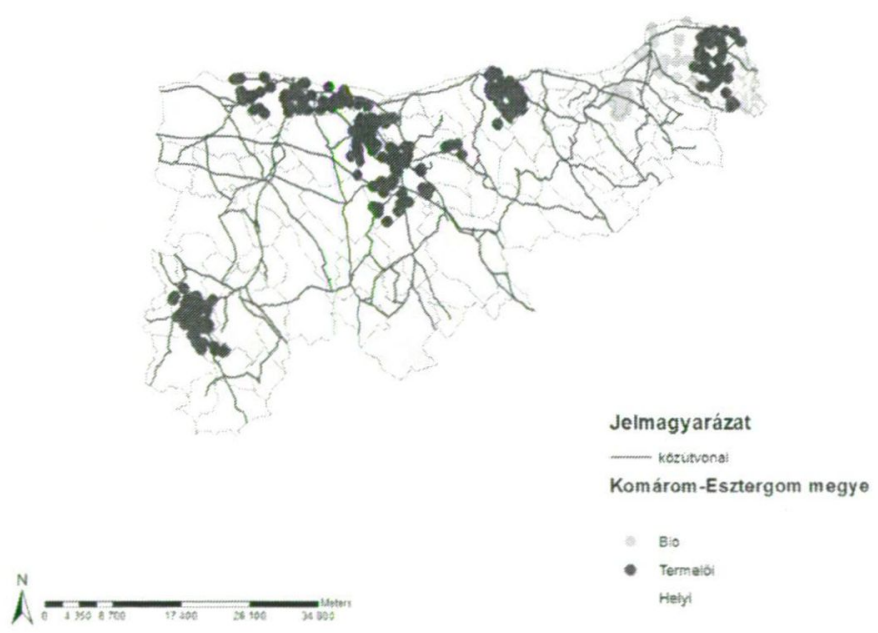

Forrás: NAK valamint naturportal.hu adatai alapján saját szerkesztés

Heves megyében 2013-ban 13532 darab egyéni gazdaságot tartottak számon, melynek 46\%-a termelt értékesítési célra. A kisgazdaságok dominanciája köszönhetően a mátrai borvidéknek tradicionálisan a szőlőtermesztésben és feldolgozásban, valamint a gyümölcstermesztésben domináns. Ez visszaköszön a helyi termékek körén is, hiszen 41 darab borászati termék mellett nagyságrendileg a szántóföldi növénytermesztésből származó termékek, a feldolgozott termékek közül 
a kenyér, pékárú követték. Az állattartáshoz kapcsolódó termékek nagyságrendileg csupán a 4. helyre kerültek, a megye termelési sajátosságainak köszönhetően (domináns a baromfi tartás), nagy a hús és tojás termékek száma. A turisztikai szempontból is releváns termékek közé a borokon kívül az édesség készítés jelenik meg, azonban ez csak két darab terméket jelent. Összesen 100 darab helyi terméket tudtunk a 2013-as évben végzett primer adat felvételezés során gyüjteni, ezek zöme a Mátra, mint tájföldrajzi egység köré szerveződött (5. ábra).

Míg a másik megyében az egyéni gazdaságok száma jóval kevesebb, 2013-ban alig haladta meg a 10000 darabot, ebből $36,5 \%$ volt az olyan gazdaság mely a saját szükségletein felül értékesítésre is termel, illetve kizárólag értékesítésre termel. A gazdaságok számának eltérése nem indokolja, hogy Komárom-Esztergom megyében talált helyi termékek száma harmad annyi lett. A 32 darab helyi termék arányosan oszlott meg az egyes kategóriák között, a tejtermékek, valamint az állattartásból származó alapanyagok aránya volt alacsonyabb (6. ábra).

\section{5. ábra: Helyi termékek, termékcsoportok település szerinti megoszlása a Heves megyei vizsgálati területen, 2017}

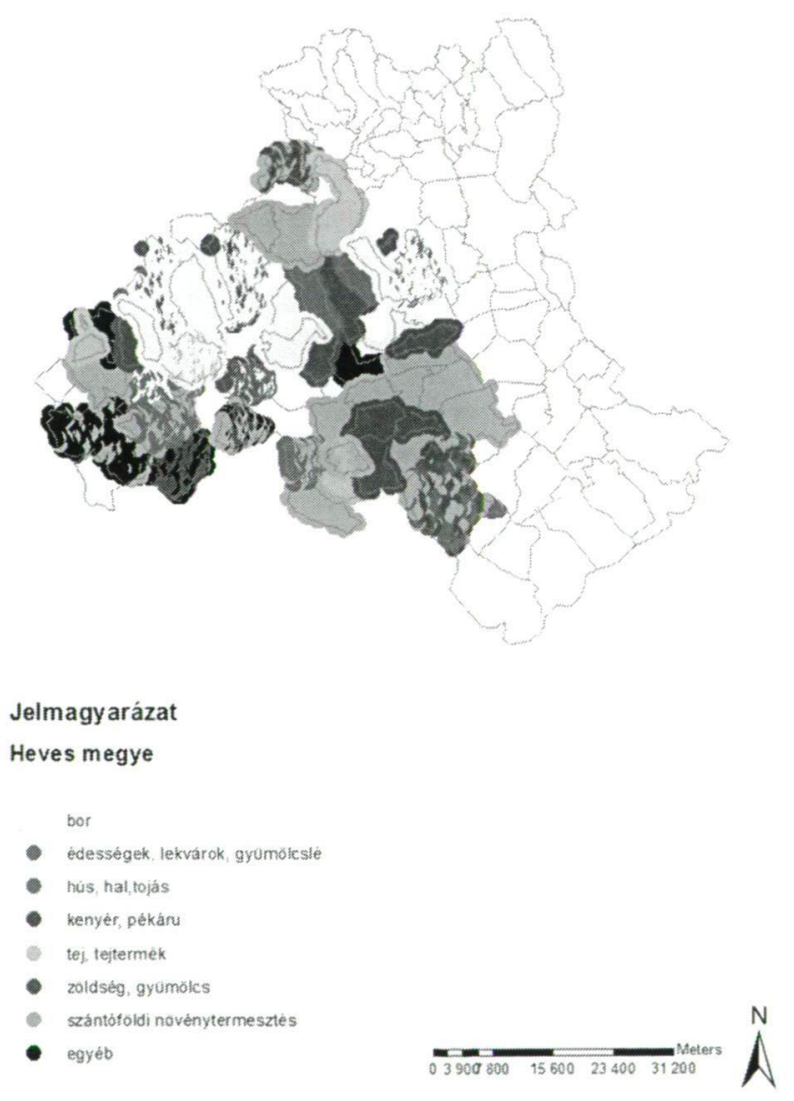

Forrás: Saját kutatás 
A helyi termékek védjegyeztetése, vagy földrajzi árujelzővel való ellátása a jelenlegi programozási ciklusban is támogatást élvez. Azonban hasznosságukat a szakirodalmi és kutatási eredmények több esetben megkérdőjelezik. Az általunk vizsgált termékek körére legyüjtött hivatalos adatok szerint egyetlen bejelentett védjegyet találtunk („HELYI TERMÉK ISTER-GRANUM”), mely esetében az oltalmi státusz fenn áll. A területi szintü adatok összehasonlítása arra enged következtetni, hogy a termék védjegyek valóban nem teljesítik be azt a szerepet, melyet marketing eszközként tőlük várnak.

\section{6. ábra: Helyi termékek, termékcsoportok település szerinti megoszlása a Komárom-Esztergom megyei vizsgálati területen, 2017}

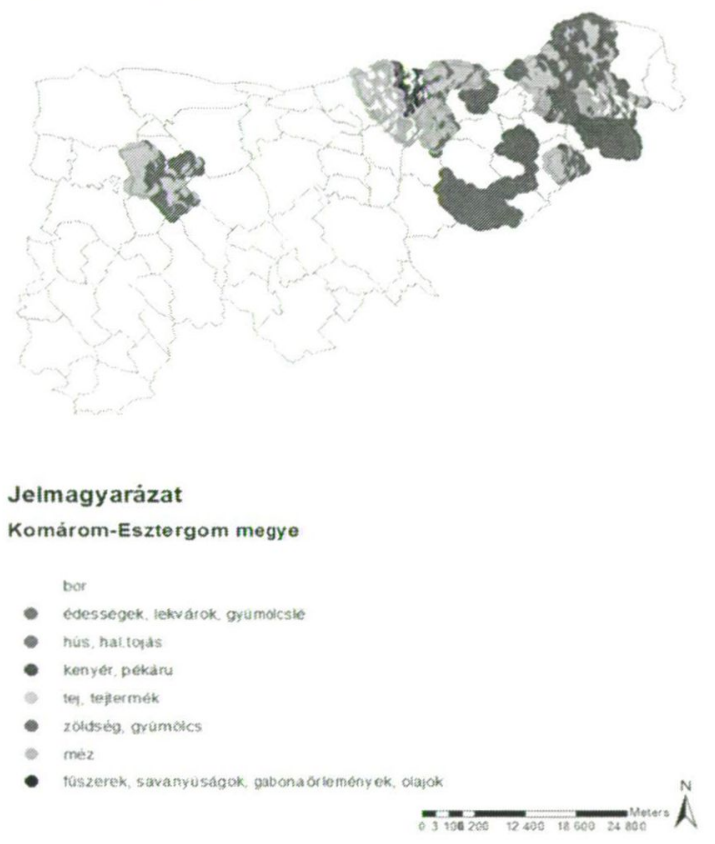

Forrás: Saját kutatás

A REL-ek fejlesztését célzó európai uniós forrásokat biztosító pályázati kiírás (VP3-16.4.1-17 Együttműködések támogatása a REL és a helyi piacok kialakításáért, fejlesztéséért és promóciójáért) esetében a kötelezően és választhatóan megvalósítandó tevékenységeket és a pályázók körét vetettük össze a szakirodalmi és saját vizsgálatunkban talált eredményekkel, megállapításokkal. A kiírás által meghatározott pályázók körét a termék elöállítók és értékesítést végzők lefedik. A kötelező tevékenységek közé tartozik a termelői együttműködésen alapuló, rövid ellátási láncú értékesítési üzleti modelljének kialakítása és működtetése, ennek érdekében új REL csoport kialakítása és müködtetése. Továbbá már létező RELjellegü közvetlen értékesítést végző csoport esetén bármilyen új projekt megvalósítása. Ehhez kapcsolódóan a pályázati kiírás bírálati szempontrendszerében legalább 5 legfeljebb 10 fős együttmủködések kaphatnak támogatást, melyek 
legalább 5 mezögazdasági termékkört ölelnek fel, és legalább kétféle értékesítési formát valósítanak meg. Saját vizsgálataink és szakirodalmi adatok alapján a közvetlen értékesítésben a zöldség, gyümölcs, méz, tojás, valamint a tejtermékek dominálnak. Tehát elsősorban a friss feldolgozatlan alapanyagok értékesítésével foglalkozó termelök és termékkörök jelenhetnek meg. A közelmúltban végzett felmérések alapján a termelöi piac, a gazdaudvarból történő közvetlen értékesítés, valamint a termelöi boltok igénybevételi gyakorisága volt a legnagyobb a közvetlen értékesítésben (Lehota-Mácsai, 2012).

A termelöi piacok bővítése önmagában kívánatos cél, hiszen számuk jelenleg alacsony, azonban a termelöi boltokkal és gazdaudvarok müködtetésével nehezen kapcsolható össze. Ezentúl fontos kérdés a gazdák szövetkezési hajlandósága, mely közismerten nagyon alacsony. A két vizsgált megyében a termelöi csoportok száma Heves megye esetében hat, Komárom-Esztergom megye esetében mindösszesen 5 darab. Termelöi szervezet csak Hevesben jelenik meg, csupán egy darab. Bár az önállóan nem támogatható tevékenységek körében a piac létesítéséhez szükséges épületek biztosítását, a termékek szállítását, piaci értékesítését segítő promócióját biztosító tevékenységek is megjelennek, ezek valószínüleg nem lesznek elegendőek az új szerveződések létrehozásához.

\section{Következtetések}

A vizsgálati mintaterületeken és a szakirodalmi adatok, eredmények alapján megállapítható, hogy a rövid ellátási láncok kialakulásának akadályai nem csak a termékpályák alacsony termék kibocsátásából és a speciálisan a helyi termékeket preferáló értékesítési csatornák szükösségén múlnak majd. Erősen determinálja a területi fejlettségbeli különbségekböl eredő keresleti-kínálati anomália, emiatt a termékek és a fogyasztók nehezebben találnak egymásra (ahol több a termék kevesebb az értékesítési lehetöség, míg a fizetőképes kereslettel rendelkező térségekben termék szükösség állhat elö). A helyzet megoldását célzó együttmüködések és helyi piacok kialakításának támogatása elérhető, azonban az együttmüködések hiánya, a termékkörök szükössége, valamint a termékek marketinget támogató védjegy rendszer bizonyítottan alacsony hatékonysága miatt nem jelent rövid távon sem megoldást. A jelenlegi programozási időszak végéig, a kiírás által elvárt, $45 \mathrm{db}$ müködő REL zömében a fentebb említett okok miatt a nagy forgalmat és árrést biztosító Közép- magyarországi régióban fognak megvalósulni és közvetlenül segíteni a helyi gazdaság fejlődését.

\section{Köszönetnyilvánítás}

A kutatást az EFOP-3.6.2-16-2017-00001 „Komplex vidékgazdasági és fenntarthatósági fejlesztések kutatása, szolgáltatási hálózatának kidolgozása a Kárpát-medencében"" címü projekt támogatta." 


\section{Irodalomjegyzék}

Benedek Zs., Balázs B. (2014): Az élelmiszertermelés relokalizációjának térbeli-társadalmi különbségei Magyarországon. Tér és Társadalom, 28 (4): 63-75.

Bocskay et al. (2013): Adj Helyet a Helyinek" Hálózati mozgalom a helyi termék polcok életre hívására (Elemzö háttéranyag). Pannon Helyi Termék Nonprofit Kft.

EIP-AGRI Focus Group (2015): Innovative Short Food Supply Chain management. Final report, 2015. Europen Comission EIP-AGRI Agriculture and Innovation. Environment and planning A., 35: 393-412.

EU Rural Review (2012): Local Food and Short Supply Chains. EU Rural Review, 12: 4-10.

European Network for Rural Development. EU Rural Review No 22 'Smart and competitive food and drink supply chains'.

J. Dwyer, K. Kubinakova, N. Lewis,J. Powell, M. Vigani, B. Fährmann, A.Gocht,R. Grajewski, M. C. Sauras, P. N. Cachinero, F. Mantino, M. BerrietSolliec, Hai-vu Pham (2016): Research for AGRI Committee - Programmes implementing the 2015-2020 Rural Development Policy. European Parliament Directorate-general for internal policies, 26-33.

Kiss K., Takácsné Gy. K. (2017): Lehet-e termelöi összefogás a REL-ek mentén? In: Szabó G., Baranyai Zs. (szerk.): A szövetkezés-együttmüködés akadályai, feltételei és fejlesztési lehetöségei a magyar élémiszergazdaságban. Agroinform Kiadó, Budapest, 271-291.

Kneafsey, M., Venn, L., Schmutz, U., Balázs, B., Trenchard, L., Wood T. E., Bos, E., Sutton, G., Backett, M. (2013): Short Food Supply Chains and Local Food Systems in the EU. A State of Play of their Socio-Economic Characteristics. European Commission Joint Research Centre Institute for Prospective technological Studies, Luxembourg,109-116.

Kujáni K. (2014): Az alternatív élelmiszerellátó rendszerek meghatározásának és csoportotsításának tényezöi. Gazdálkodás. 58 (1): 30-40.

Lehota J., Csíkné M. É.: Értékesítési sajátosságok - közvetlen értékesítési csatornái. In: Szakály Z., Szente V. (szerk.): Agrártermékek közvetlen értékesítése, marketingje. Magyar Agrárkamara, Szaktudás, Budapest, 117155.

Renting, H. , Marsden, T. K. , Banks, J. (2003): Understanding alternative food networks: exploring the role of short food supply chains in rural development. Environment and Planning A, 35 (3): 393-411.

Short food supply chains and local food systems in the EU (2016). In: Marie-Laure Augère-Granier (szerk.): EPRS - European Parliamentary Research Service. 10.

Szabó E. (2006): Az eredet-és minőségjelzök alkalmazásának lehetőségei és feltételei a marketingkommunikációban. PhD értekezés. Budapesti Corvinus Egyetem, Budapest. 